\title{
Optimization study of fructans extraction from Agave tequilana Weber azul variety
}

\author{
Jesús Aarón SALAZAR-LEYVA, Idalia OSUNA-RUIZ¹, Víctor Alfonso RODRÍGUEZ-TIRADO1, \\ Iris Eréndira ZAZUETA-PATRÓN ${ }^{1}$, Héctor Daniel BRITO-ROJAS ${ }^{1}$
}

\begin{abstract}
Agave tequilana Weber azul variety is a valuable source of fructans. In this study, a response surface methodology was employed to optimize the extraction yield of fructans from agave pines. A Box Behnken factorial design was applied to evaluate the effects of several conditions such as extraction temperature, water raw material ratio and extraction time on extraction yield. Under the optimum extraction conditions (extraction temperature of $79.1{ }^{\circ} \mathrm{C}$, water raw material ratio of $5.13 \mathrm{~mL} / \mathrm{g}$, and extraction time of $1.48 \mathrm{~h}$ ) fructans extraction yield was $83.12 \%$. The chromatographic profile of the agave crude extract presented four peaks, out of which fructans were the most preponderant $(\sim 87 \%)$. The obtained results suggest that the response surface methodology is adequate to optimize fructans extraction from Agave tequilana Weber azul variety.
\end{abstract}

Keywords: fructans; agave; extraction yield; optimization; response surface methodology.

Practical Application: Response surface methodology allows the optimization of fructans extraction from Agave azul.

\section{Introduction}

Fructans are carbohydrates that consist mostly of fructose, and in a minor proportion of glucose. These kinds of compounds have one or more fructosyl-fructose linkages which constitutes the majority of them. Fructans structures can be linear or branched, and can have different degrees of polymerization (DP). According to the way that fructofuranosyl units are linked, these biomolecules are classified as inulin, levan, phlein, graminan, and kestoses (Roberfroid, 2005). Due to the fact, that fructans cannot be digested by humans they are low-calorie food, stimulating the growth and activity of beneficial bacteria in the colon (Gomez et al., 2010; Robinson, 1995). Moreover, many authors have been reporting that fructans may act as fat substitutes because of their ability to add texture and to improve rheological characteristics of dairy products (Akın et al., 2007; Pimentel et al., 2013).

Most plants store starch as a reserve carbohydrates, however at least 10 families of higher plants store fructans in a soluble form in vacuoles, leaves, roots, stems, tubers, or kernels (Roberfroid, 2005; Vijn \& Smeekens, 1999). So far, the plants that have been used industrially for the extraction of fructans are chicory (Cichorium intybus) and Jerusalem artichoke (Helianthus tuberosus) (Paseephol et al., 2007; Toneli et al., 2007). A natural source, rich in fructans is the Agave plant. These kinds of vegetables grow in Mediterranean and hot climates, being Mexico considered as the center of origin and biodiversity of Agave species (Ávila-Fernández et al., 2011; Furlán et al., 2014). Heads of plants belonging to the agave genus have high contents of fructan oligomers, composed mainly of fructose units linked to a sucrose molecule. These agave fructans consist of a complex mixture of fructooligosaccharides, containing principally $\beta(2-1)$ and $\beta$ (2-6) linkages (Lopez et al., 2003; Mancilla-Margalli \& López, 2006). Mexico has a considerable production of agave, and particularly the Agave tequilana Weber azul variety is grown commercially for the production of the worldwide famous alcoholic beverage tequila (Bautista-Justo et al., 2001). Recently, alternative industrial usages for agave plants have emerged, such as the production of syrups and agave fructans, being Agave tequilana Weber azul variety the raw material most utilized for these purposes (Ávila-Fernández et al., 2011; Narváez-Zapata \& Sánchez-Teyer, 2009).

The industrial extraction process of fructans from vegetal sources, is generally based on diffusion of polysaccharides in hot water (Apolinário et al., 2014; Kim et al., 2001). In this sense, several investigations have been developed to set optimum extraction conditions of fructans extraction from plants, and temperature, extraction time, and water raw material ratio were identified as the most important factors influencing the extraction yield (Abozed et al., 2009; Lingyun et al., 2007; Paseephol et al., 2007). Despite the important role of Agave tequilana Weber azul variety as raw material to obtain fructans, little information is available about their extraction by hot water diffusion. Therefore, the objective of this study was to optimize the extraction process of Agave tequilana fructans by using hot water as a solvent. The response surface methodology was used to optimize extraction conditions (temperature, extraction time and water raw material ratio) in order to obtain the maximal fructans extraction yield. In addition Agave tequilana fructans obtained under the optimal 
conditions were analyzed using High Performance Liquid Chromatography (HPLC).

\section{Materials and methods}

\subsection{Plant material}

Six-year-old Agave tequilana Weber azul variety plants were harvested in an agricultural field near Mazatlan, Sinaloa, Mexico. The stem of the plant (usually called "head" or "pine") was fragmented, washed with distilled water, and maintained at $-22{ }^{\circ} \mathrm{C}$ for further use.

\subsection{Reagents}

Standards of chicory inulin, sacarose, fructose and glucose were purchased from Sigma-Aldrich (St. Louis, MO, USA). The water used for the chromatographic analyses was HPLC grade (Fisher-scientific, Pittsburgh, USA). A commercial kit for fructans determination was purchased from Megazyme (Wicklow, Ireland). All other chemicals and solvents used were of analytical grade.

\subsection{Extraction of Agave tequilana fructans}

In this study, a solid liquid extraction was done by using distilled water, considering the high solubility of fructans in this solvent. Agave pines were thawed at room temperature, and homogenized with water in a blender (International, LI-3, Mexico). The $\mathrm{pH}$ solution was adjusted to 5.5 to avoid acid hydrolysis of polysaccharides. Different extractions conditions were evaluated (temperature, extraction time and water raw material ratio), as it is detailed in section 2.7. The liquid extract obtained at the end of the extraction process was filtered to eliminate the solid fraction, and centrifuged (Thermo-Fisher Scientific, Sorvall, Waltham, USA) at $10,000 \times \mathrm{g}$, for $10 \mathrm{~min}$ to remove suspended particles. The supernatant was considered as the fructans crude extract. All extraction experiments were performed in duplicate.

\subsection{Determination of total carbohydrate}

Total carbohydrate was determined by the phenol sulphuric acid method (Dubois et al., 1956) with slight modifications proposed by Fox \& Robyt (1991). Samples of agave fructans $(300 \mu \mathrm{L})$ were mixed with $300 \mu \mathrm{L}$ of $5 \%$ phenol solution. The mixture was placed in an ice bath and $1500 \mu \mathrm{L}$ of $96 \%$ sulphuric acid was added. After an incubation at $80^{\circ} \mathrm{C}$ for $30 \mathrm{~min}$, the solution appeared as orange color and its absorbance was measured at $492 \mathrm{~nm}$ using a UV-vis spectrophotometer (Jenway, 6305, Staffordshire, UK). Series of fructose solutions of known concentration were used to establish a standard curve.

\subsection{Reducing sugar measurement}

Reducing sugar content in agave fructans was measured using the dinitrosalicylic acid (DNS) method (Miller, 1959) with slight modifications. Briefly, $100 \mu \mathrm{L}$ of agave fructans solution was mixed with $100 \mu \mathrm{L}$ of DNS reagent. After mixing it with a vortex, samples were heated in a water bath at $100^{\circ} \mathrm{C}$ for $5 \mathrm{~min}$., followed by cooling to room temperature. Later $1600 \mu \mathrm{L}$ of distilled water was added. The absorbance was recorded at $535 \mathrm{~nm}$. A calibration curve was prepared using fructose as standard.

\subsection{Determination of fructans extraction yield}

Fructans content in the crude extract was calculated with the difference between total carbohydrate and reducing sugar (Lingyun et al., 2007), whereas the quantification of fructans in the plant material was assessed by the fructan assay procedure kit Megazyme (McCleary et al., 2000). Then, fructans extraction yield (FEY) was calculated as shown below (Equation 1):

$$
\text { FEY }(\%)=\frac{\text { Fructans crude extract }(g)}{\text { Fructans plant material }(g)} \times 100
$$

\subsection{Experimental design and statistical analysis}

Prior to the optimization study, a preliminary screening was conducted to determine the effect of extraction temperature, extraction time, and water raw material ratio over the variable response fructans extraction yield (FEY). To evaluate the effect of temperature, this factor was set at $60,70,80$, and $90^{\circ} \mathrm{C}$. The other extraction condition was water raw material ratio fixed at $4 \mathrm{~mL} / \mathrm{g}$, and extraction time 1 hour. Also extraction time was evaluated, setting this factor at 1,2,3 and $4 \mathrm{~h}$ whereas water raw material ratio and extraction temperature were maintained at $4 \mathrm{~mL} / \mathrm{g}$ and $80^{\circ} \mathrm{C}$ respectively. In addition, water raw material ratio was evaluated at $1,3,6,9$, and $12 \mathrm{~mL} / \mathrm{g}$. Other extraction conditions were maintained as follows: extraction time $1 \mathrm{~h}$ and extraction temperature $80^{\circ} \mathrm{C}$. Based on the results of the preliminary screening, a three-level, and three variable Box-Behnken factorial design (BBD) was applied. The evaluated factors and their coded and uncoded levels are shown in Table 1. Response Surface Methodology (RSM) was used to investigate the optimum levels of the factors and their relationships. The complete design consisted of fifteen combinations including three replicates of the center point. The experimental runs were performed in a totally random order, and the experimental data was analyzed by means of a second order model (Equation 2):

$$
Y=\sum A_{0}+\sum_{i=1}^{3} A_{i} X_{i}+\sum_{i=1}^{3} A_{i i} X_{i}^{2}+\sum_{i=1}^{2} \sum_{j=i+1}^{3} A_{i j} X_{i} X_{j}
$$

where $Y$ is the response variable, $A_{0}, A_{\mathrm{i}}, A_{\mathrm{ii}}, A_{\mathrm{ij}}$ are the regression coefficients of variables for intercept, linear, quadratic and interaction coefficients respectively, and $X_{\mathrm{i}}$ and $X_{\mathrm{i}}$ are independent variables.

Table 1. Coded levels of the experimental factors for Box-Behnken design matrix.

\begin{tabular}{lcccc}
\hline \multirow{2}{*}{ Factor } & $\begin{array}{c}\text { Coded } \\
\text { symbols }\end{array}$ & -1 & 0 & 1 \\
\cline { 3 - 5 } $\begin{array}{l}\text { Temperature } \\
\left({ }^{\circ} \mathrm{C}\right)\end{array}$ & $\mathrm{X} 1$ & 60 & 75 & 90 \\
Time $(\mathrm{h})$ & $\mathrm{X} 2$ & 1 & 1.5 & 2 \\
$\begin{array}{l}\text { Ratio of } \\
\text { water to raw }\end{array}$ & $\mathrm{X} 3$ & 3 & 6 & 9 \\
$\begin{array}{l}\text { material } \\
(\mathrm{mL} / \mathrm{g})\end{array}$ & & & & \\
\hline
\end{tabular}


The verification of the model adequacy with the experimental data was done using the coefficient of determination $\left(R^{2}\right)$, Absolute Average Deviation value (AAD) and the lack of fit test. AAD was calculated according to the Equation 3:

$$
A A D=\left\{\left[\sum_{i=1}^{p}(|y i, \exp -y i, c a l| / y i, \exp )\right] / p\right\} \times 100
$$

where $y_{i, \exp }$ and $y_{i, \text { cal }}$ are the experimental and calculated responses respectively, and $p$ is the number of experimental run. The software package used was STATGRAPHICS Plus Version 5.1 (StatPoint Inc., Warrenton, USA).

\subsection{High performance liquid chromatographic analysis of fructans crude extract}

The crude extract obtained under the optimal conditions of extraction, were analyzed using the method of Marsilio et al. (2000) with slight modifications. The liquid chromatography apparatus consisted of a Varian Polaris HPLC system with an evaporative light scattering detector (ELS-2100) (Varian Inc., Palo Alto, USA). Parameters of the ELS-2100 detector were as follows: gas flow rate $0.9 \mathrm{slm}$ (standard liter per minute), evaporation

a

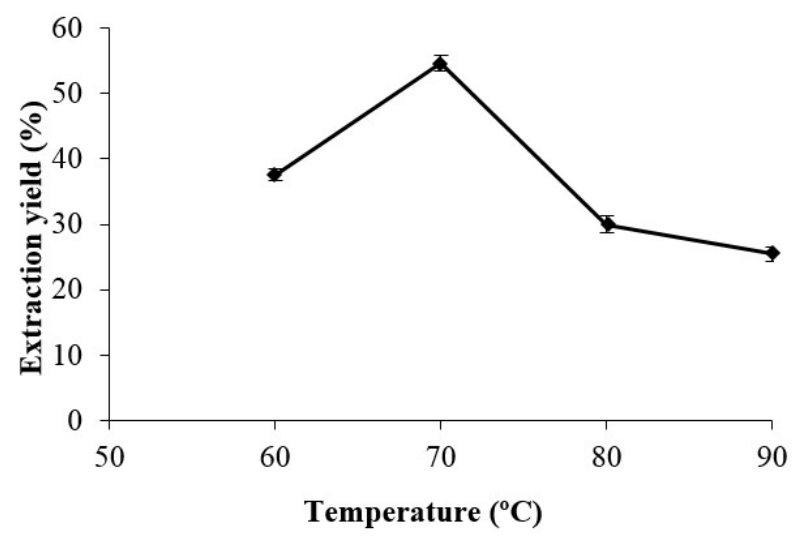

and nebulization temperature at 90 and $80{ }^{\circ} \mathrm{C}$ respectively. The extracts were diluted until it was necessary and filtered prior to analysis, by using a nylon syringe filter $(4 \mathrm{~mm}$ diameter, $0.2 \mu \mathrm{m}$ size pore). The chromatographic separation was carried out using a MetaCarb $87 \mathrm{C}$ column $(300 \times 7.8 \mathrm{~mm})$ (Varian Inc., Palo Alto, USA). HPLC grade water was used as mobile phase at a flow rate of $0.6 \mathrm{~mL} / \mathrm{min}$ keeping the column temperature at $85{ }^{\circ} \mathrm{C}$. The injected sample volume was $20 \mu \mathrm{L}$. Chicory inulin, sacarose, glucose and fructose standards were used to compare it with the carbohydrates contained in the analyzed sample. In addition, a calibration curve was constructed using chicory inulin as a external standard in a concentration range of 0.05 to $0.45 \mathrm{mg} / \mathrm{mL}$.

\section{Results and discussion}

\subsection{Preliminary screening}

As it was previously stated in section 2.7., a single factor test was done, exploring the factors of extraction temperature, extraction time, and water raw material ratio. According to Figure 1a the highest fructans extraction yield (FEY) was obtained at a temperature of $70{ }^{\circ} \mathrm{C}$, whereas at $90{ }^{\circ} \mathrm{C}$ FEY decreased drastically. Cai et al. (2008) found a similar behaviour in a crude

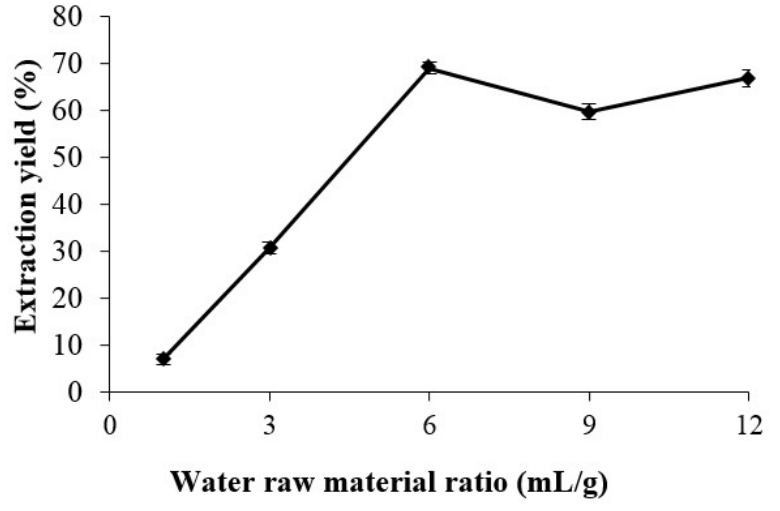

Figure 1. Effect of extraction temperature (a), extraction time (b) and water raw material ratio (c) on fructans extraction yield. Bars represent the standard deviation. Each value is a mean of three replicates $(n=3)$. 
extract of polysaccharides from Opuntia milpa alta and reported that the decrease in extraction yield was due to the hydrolysis of polysaccharides at higher temperatures. The effect of time on fructans extraction yield is depicted in Figure $1 \mathrm{~b}$, and from this graph is possible to observe a slight increase on FEY during the first three hours. Later, extraction yield was decreasing. These results suggest that in the three first hours, fructans extraction yield maintain a dynamic equilibrium, nevertheless when extraction time was increased, fructans extraction yield decreased. Previous studies (Cai et al., 2008; Yin \& Dang, 2008) reported that excessive extraction time induces polysaccharides extraction yield to decrease probably, due to hydrolysis of carbohydrate molecules. Aditionally, the effect of water raw material ratio on fructans extraction yield was evaluated. In this regard, in Figure $1 \mathrm{c}$, it is observed that within the range of 1 to $6 \mathrm{~mL} / \mathrm{g}$ of water raw material ratio, the extraction yield increased, and reached the highest value when the ratio was $6 \mathrm{~mL} / \mathrm{g}$. Similar results were observed by Yin \& Dang (2008) and Yan et al. (2014) when extracted polysaccharides from $\mathrm{BaChu}$ mushroom and leaves of Gynura bicolor respectively. These authors mentioned that the increase of water raw material ratio may increase diffusivity of the solvent into vegetable cells, so desorption of the polysaccharides from the cells is enhanced. However, when the ratio is higher than $6 \mathrm{~mL} / \mathrm{g}$, fructans extraction yield slightly decreased and no longer changed.

\subsection{Optimization study of crude fructans extraction using the Box-Behnken factorial design}

According to the levels and factors showed in Table 1, the software package STATGRAPHICS Plus Version 5.1 (StatPoint Inc., Warrenton, VA, USA) proposed a matrix design with 15 experimental combinations. Table 2 shows the matrix design with the experimental and predicted results of the response fructans extraction yield $(Y)$. In this research, the fructans extraction yield (FEY) ranged from $19.21 \%$ to $82.14 \%$. A maximum value was found in experiment number 13, under the experimental conditions of temperature $75^{\circ} \mathrm{C}$, extraction time $1.5 \mathrm{~h}$, and water raw material ratio $6 \mathrm{~mL} / \mathrm{g}$ (Table 2). Furthermore, a regression analysis was applied to the experimental data, the response variable, and the studied factors, resulting in the following Equation 4:

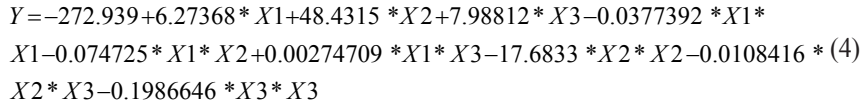

where $Y$ is the response variable (\%), $\mathrm{X} 1$ is temperature extraction $\left({ }^{\circ} \mathrm{C}\right), \mathrm{X} 2$ is extraction time $(\mathrm{h})$, and $\mathrm{X} 3$ is water raw material ratio $(\mathrm{mL} / \mathrm{g})$.

Table 3 shows a summary of the analysis of variance (ANOVA) applied to the second order model. The $p$ value of the model was less than 0.05 , indicating that it is a significant model. Moreover, the lack of fit was non-significant $(p \geq 0.05)$ implying that the model accurately represents the data in the experimental region. Besides the lack of fit test, the coefficient of determination $R^{2}$ is a widely accepted parameter for verification of the model adequacy (Baş \& Boyac1, 2007). In this regard, the $R^{2}$ was calculated as 0.9145 indicating that the statistical model explains $91.45 \%$ of the variability in the fructans extraction yield. When the statistical
Table 2. Matrix design and results from Box-Behnken factorial design.

\begin{tabular}{clllll}
\hline & & \multicolumn{3}{c}{$\begin{array}{c}\text { Fructans extraction yield }(\%)^{\mathrm{a}} \\
\text { Experimental } \\
\text { Predicted }\end{array}$} \\
\hline 1 & 0 & 1 & 1 & $48.52 \pm 1.23$ & 54.21 \\
2 & 1 & 0 & 1 & $57.23 \pm 0.53$ & 48.45 \\
3 & 0 & 1 & -1 & $66.45 \pm 0.95$ & 55.17 \\
4 & 1 & 0 & -1 & $55.34 \pm 0.91$ & 63.23 \\
5 & 0 & -1 & 1 & $61.05 \pm 1.82$ & 66.19 \\
6 & -1 & 0 & -1 & $31.89 \pm 0.55$ & 29.23 \\
7 & 0 & 0 & 0 & $80.15 \pm 0.74$ & 81.94 \\
8 & -1 & 1 & 0 & $19.21 \pm 0.85$ & 26.17 \\
9 & -1 & -1 & 0 & $31.12 \pm 0.25$ & 35.11 \\
10 & 0 & 0 & 0 & $73.34 \pm 1.19$ & 75.03 \\
11 & 1 & -1 & 0 & $62.21 \pm 0.74$ & 53.12 \\
12 & 1 & 0 & 1 & $44.70 \pm 1.25$ & 47.87 \\
13 & 0 & 0 & 0 & $82.14 \pm 0.7$ & 79.91 \\
14 & 1 & 1 & 0 & $39.65 \pm 0.34$ & 37.15 \\
15 & 0 & -1 & -1 & $69.02 \pm 2.1$ & 69.23 \\
\hline
\end{tabular}

${ }^{\mathrm{a}}$ Experimental fructans extraction yield are averages \pm standard deviation from three independent experiments.

Table 3. Summary of the analysis of variance of the polynomial model for the response fructans extraction yield $(Y)$.

\begin{tabular}{cl}
\hline Source & $p$ value \\
\hline Model & $0.0123^{\star}$ \\
$\mathrm{X} 1$ & $0.0254^{*}$ \\
$\mathrm{X} 2$ & $0.0319^{*}$ \\
$\mathrm{X} 1^{\star} \mathrm{X} 1$ & $0.0018^{\star}$ \\
$\mathrm{X} 1^{\star} \mathrm{X} 3$ & $0.0274^{\star}$ \\
$\mathrm{X} 2^{\star} \mathrm{X} 2$ & $0.0128^{\star}$ \\
$\mathrm{X} 3^{\star} \mathrm{X} 3$ & 0.1745 \\
Lack of fit test & 0.2744 \\
\hline
\end{tabular}

${ }^{*}$ Significant at $p<0.05$.

model has several terms, it is recommendable to calculate the adjusted $R^{2}\left(R_{A d}^{2} j\right)$, because this adjusted value corrects the $R^{2}$ value for the sample size and the numbers of terms of the model (Box et al., 1978). In this context, the obtained $R_{A d}^{2} j$ value from the regression analysis applied to our model was 0.8413 and was considered adequate to advocate the significance and prediction of our model. Other parameter that was used to check the accuracy of the model is the Absolute Average Deviation (AAD). The AAD between the predicted and experimental data must be as small as possible. In this regard, the $\mathrm{AAD}$ value was very small (0.000365) indicating that the model has a good fitness and it is adequate to describe the observed data of the response $Y$. In addition, from the ANOVA table it is possible to establish the significance level of each coefficient of the model and the interaction between the evaluated factors. In this study, the linear terms X1 (temperature extraction) and X2 (extraction time) affect significantly $(p<0.05)$ the response FEY. Other studies reporting the significant influence of temperature and time on extraction yield of polysaccharides from vegetable sources are those conducted by XuJie \& Wei (2008) and Yan et al. (2014). Also, Bouaziz, et al. (2014) observed that water temperature had a significant influence on the extraction yield of polysaccharides from Agave americana leaves. Moreover, a significant interaction $(p<0.05)$ was observed for the quadratic terms $\mathrm{X}^{\star}{ }^{\star} \mathrm{X} 1, \mathrm{X} 2{ }^{\star} \mathrm{X} 2$ 
and $\mathrm{X} 1^{*} \mathrm{X} 3$. (Table 3 ). And in fact, the high significance of the $\mathrm{X} 1$ and $\mathrm{X} 2$ second order model indicates that even small variations in temperature and extraction time, can cause significantly alterations on fructans extraction yield.

The relationships between the response $Y$ (fructans extraction yield) and the independent variables can be better understood by examining the response surface plots generated from the prediction model (Equation 4). Figure 2a shows the effect of extraction time (X2) and water raw material ratio (X3) on fructans extraction yield $(\mathrm{Y})$. Temperature was fixed at level 0 . Fructans extraction yield decreased dramatically when extraction time increased beyond $1.4 \mathrm{~h}$. The water raw material ratio also affects the evaluated response; while this factor increased beyond $6 \mathrm{~mL} / \mathrm{g}$, extraction yields decreased. Figure $2 \mathrm{~b}$ shows the effect of extraction temperature (X1) and extraction time (X2) at a fixed level of water raw material ratio, suggests that the maximum fructans extraction yield is near $80^{\circ} \mathrm{C}$, and beyond this temperature the extraction yield decreased. This behaviour could be related with the susceptibility of agave fructans to hydrolysis at elevated temperatures. Interestingly, by observing Figure $2 \mathrm{~b}$ it is evident the significant influence $(p<0.05)$ of temperature and extraction time over the variable response. Figure $2 c$ shows the influence of extraction temperature (X1) and water raw material ratio (X3) at a fixed extraction time (0 level). From this figure, it can be observed that small variations on extraction temperature cause significantly changes on fructans extraction. This result is related to the second order interaction $\left(\mathrm{X} 1{ }^{*} \mathrm{X} 1\right)$ resulting from the ANOVA.
The optimum conditions of the different independent variables (extraction temperature of $79.1^{\circ} \mathrm{C}$, water raw material ratio of $5.13 \mathrm{~mL} / \mathrm{g}$, and extraction time of $1.48 \mathrm{~h}$ ) were obtained by solving the model equation (Equation 4), where the maximum predicted $Y$ value was $82.17 \%$. The model was validated with additional experiments under the predicted conditions and the experimental value of the variable response was $83.12 \% \pm 1.99$ (average of three replicates), which was in agreement with the prediction of the model.

\subsection{Analysis of agave crude extract by HPLC}

The fructans crude extract obtained under the optimal extraction conditions was analyzed by HPLC. It is important to mention that the chromatographic analysis used in this research is not able to show detailed structural information of the polysaccharides present on the sample. However, by comparing the retention times of the utilized standards and the carbohydrates of the agave crude extract, it is possible to confirm that the studied sample contains fructans and other sugars. Then, the retention time (RT) of peak 1 is very close to the RT of chicory inulin. On the other hand, peaks 2, 3, and 4 could be related with the presence of sacarose, glucose, and fructose, respectively on the agave crude extract (Table 4). The quantification of agave fructans (peak 1) was done using a calibration curve of chicory inulin, and fructans where the principal carbohydrates contained on the sample, representing the $86.19 \%$ respect to total carbohydrates content. These results agree with the investigation of Mancilla-Margalli \& López (2006), where they reported that fructans represents more than $60 \%$ of water soluble carbohydrates in five different agave species. a

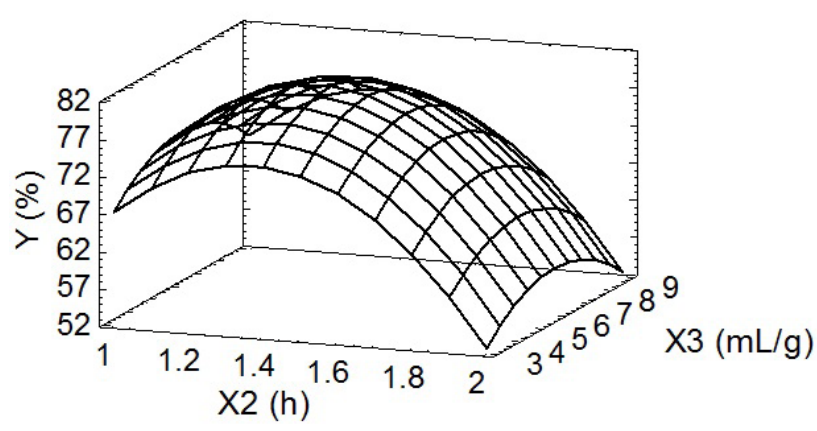

b

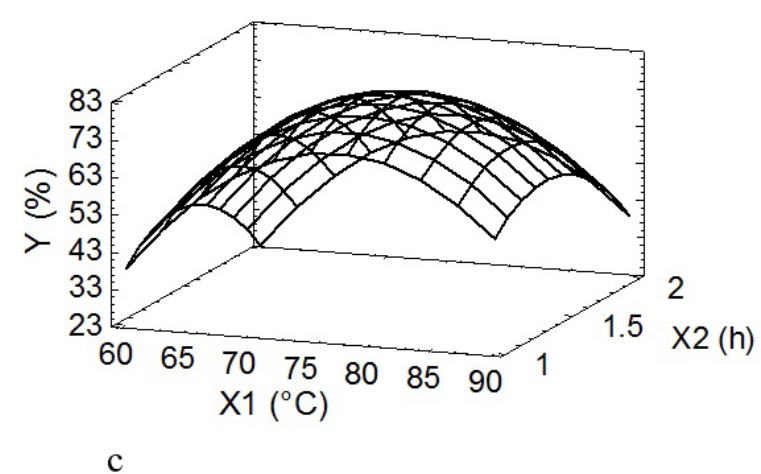

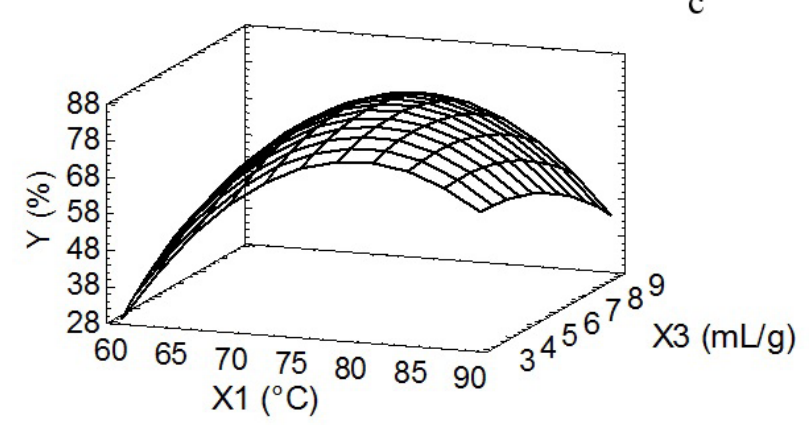

Figure 2. Response surface plots showing the effect of experimental factors on the response $Y$. (a) Extraction time, X2 vs. water raw material ratio, X3; (b) Extraction temperature, X1 vs. extraction time, X2; (c) Extraction temperature, X1 vs. water raw material ratio, X3. 
Table 4. Retention time of standards and carbohydrates present in the agave crude extract.

\begin{tabular}{cc}
\hline Sample & Retention time $(\min )^{\mathrm{a}}$ \\
\hline Peak 1 & $6.31 \pm 0.001$ \\
Chicory inulin & $6.33 \pm 0.001$ \\
Peak 2 & $7.92 \pm 0.003$ \\
Sacarose & $7.80 \pm 0.127$ \\
Peak 3 & $9.26 \pm 0.040$ \\
Glucose & $9.5 \pm 0.213$ \\
Peak 4 & $12.03 \pm 0.61$ \\
Fructose & $12.01 \pm 0.028$ \\
\hline
\end{tabular}

${ }^{a}$ Values of retention time are averages \pm standard deviation from triplicates $(n=3)$ injected in the HPLC system.

\section{Conclusions}

Fructans extraction process by hot water diffusion from Agave azul pines was optimized using the response surface methodology. The independent factors that have a significant influence $(p<0.05)$ on fructans extraction yield were temperature (X1) and extraction time (X2). Besides, several second order interactions were detected $\left(\mathrm{X} 1^{\star} \mathrm{X} 1, \mathrm{X} 2^{\star} \mathrm{X} 2\right.$ and $\left.\mathrm{X} 1^{\star} \mathrm{X} 3\right)$. A fructans extraction yield of $83.12 \%$ was achieved when optimum conditions of extraction temperature, water raw material ratio and extraction time were $79.1^{\circ} \mathrm{C}, 5.13 \mathrm{~mL} / \mathrm{g}$ and $1.48 \mathrm{~h}$ respectively. The analysis of agave fructans by HPLC allowed us to identify four peaks in the crude extract, matching with the retention time of chicory inulin, sacarose, glucose and fructose standards. Interestingly, fructans represented the majority of the carbohydrates in the agave crude extract. These results would contribute with the adequate exploitation of agave plants as raw material for the extraction and isolation of agave fructans which are valuable molecules that could be used as supplement or additive in the food industry.

\section{References}

Abozed, S., Abdelrashid, A., El-Kalyoubi, M., \& Hamad, K. (2009). Production of inulin and high-fructose syrup from Jerusalem artichoke tuber (Helianthus tuberosus L.). Annals of Agricultural Science, 54(2), 417-423.

Akın, M., Akın, M., \& Kırmacı, Z. (2007). Effects of inulin and sugar levels on the viability of yogurt and probiotic bacteria and the physical and sensory characteristics in probiotic ice-cream. Food Chemistry, 104(1), 93-99. http://dx.doi.org/10.1016/j.foodchem.2006.11.030.

Apolinário, A. C., Damasceno, B. P. G. L., Beltrão, N. E. M., Pessoa, A., Converti, A., \& da Silva, J. A. (2014). Inulin-type fructans: A review on different aspects of biochemical and pharmaceutical technology. Carbohydrate Polymers, 101, 368-378. PMid:24299785. http://dx.doi. org/10.1016/j.carbpol.2013.09.081.

Ávila-Fernández, Á., Galicia-Lagunas, N., Rodríguez-Alegría, M. E., Olvera, C., \& López-Munguía, A. (2011). Production of functional oligosaccharides through limited acid hydrolysis of agave fructans. Food Chemistry, 129(2), 380-386. PMid:25212145. http://dx.doi. org/10.1016/j.foodchem.2011.04.088.

Baş, D., \& Boyac1, İ. H. (2007). Modeling and optimization I: usability of response surface methodology. Journal of Food Engineering, 78(3), 836-845. http://dx.doi.org/10.1016/j.jfoodeng.2005.11.024.
Bautista-Justo, M., García-Oropeza, L., Barboza-Corona, J., \& ParraNegrete, L. (2001). El Agave tequilana Weber y la producción de tequila. Acta Universitaria, 11(2), 26-34.

Bouaziz, A., Masmoudi, M., Kamoun, A., \& Besbes, S. (2014). Optimization of insoluble and soluble fibres extraction from Agave americana 1. Using response surface methodology. Journal of Chemistry, 2014, 1-13.

Box, G., Hunter, W., \& Hunter, J. (1978). Statistics for experimenters: an introduction to design, data analysis and model building (1st ed.). New York: John Wiley \& Sons.

Cai, W., Gu, X., \& Tang, J. (2008). Extraction, purification, and characterization of the polysaccharides from Opuntia milpa alta. Carbohydrate Polymers, 71(3), 403-410. http://dx.doi.org/10.1016/j. carbpol.2007.06.008.

Dubois, M., Gilles, K. A., Hamilton, J. K., Rebers, P., \& Smith, F. (1956). Colorimetric method for determination of sugars and related substances. Analytical Chemistry, 28(3), 350-356. http://dx.doi. org/10.1021/ac60111a017.

Fox, J. D., \& Robyt, J. F. (1991). Miniaturization of three carbohydrate analyses using a microsample plate reader. Analytical Biochemistry, 195(1), 93-96. PMid:1888021. http://dx.doi.org/10.1016/00032697(91)90300-I.

Furlán, L. T. R., Herrera, P. A., Padilla, A. P., Basurto, R. I. O., \& Campderrós, M. E. (2014). Assessment of agave fructans as lyoprotectants of bovine plasma proteins concentrated by ultrafiltration. Food Research International, 56, 146-158. http://dx.doi.org/10.1016/j. foodres.2013.12.014.

Gomez, E., Tuohy, K., Gibson, G., Klinder, A., \& Costabile, A. (2010). In vitro evaluation of the fermentation properties and potential prebiotic activity of Agave fructans. Journal of Applied Microbiology, 108(6), 2114-2121. PMid:19941629.

Kim, Y., Faqih, M. N., \& Wang, S. S. (2001). Factors affecting gel formation of inulin. Carbohydrate Polymers, 46(2), 135-145. http:// dx.doi.org/10.1016/S0144-8617(00)00296-4.

Lingyun, W., Jianhua, W., Xiaodong, Z., Da, T., Yalin, Y., Chenggang, C., Tianhua, F., \& Fan, Z. (2007). Studies on the extracting technical conditions of inulin from Jerusalem artichoke tubers. Journal of Food Engineering, 79(3), 1087-1093. http://dx.doi.org/10.1016/j. jfoodeng.2006.03.028.

Lopez, M. G., Mancilla-Margalli, N. A., \& Mendoza-Diaz, G. (2003). Molecular structures of fructans from Agave tequilana Weber var. azul. Journal of Agricultural and Food Chemistry, 51(27), 7835-7840. PMid:14690361. http://dx.doi.org/10.1021/jf030383v.

Mancilla-Margalli, N. A., \& López, M. G. (2006). Water-soluble carbohydrates and fructan structure patterns from Agave and Dasylirion species. Journal of Agricultural and Food Chemistry, 54(20), 7832-7839. PMid:17002459. http://dx.doi.org/10.1021/jf060354v.

Marsilio, R., Naturale, M., Manghi, P., Montini, G., Murer, L., Ros, M., Bisogno, G., Andretta, B., Dussini, N., Giordano, G., Zacchello, G., \& Dall'Amico, R. (2000). Rapid and simple determination of inulin in biological fluids by high-performance liquid chromatography with light-scattering detection. Journal of Chromatography B: Biomedical Sciences and Applications, 744(2), 241-247. PMid:10993511. http:// dx.doi.org/10.1016/S0378-4347(00)00226-7.

McCleary, B. V., Murphy, A., \& Mugford, D. C. (2000). Measurement of total fructan in foods by enzymatic/spectrophotometric method: collaborative study. Journal of AOAC International, 83(2), 356-364. PMid:10772173.

Miller, G. L. (1959). Use of dinitrosalicylic acid reagent for determination of reducing sugar. Analytical Chemistry, 31(3), 426-428. http://dx.doi. org/10.1021/ac60147a030. 
Narváez-Zapata, J., \& Sánchez-Teyer, L. (2009). Agaves as a raw material: recent technologies and applications. Recent Patents on Biotechnology, 3(3), 185-191. PMid:19747148.

Paseephol, T., Small, D., \& Sherkat, F. (2007). Process optimisation for fractionating Jerusalem artichoke fructans with ethanol using response surface methodology. Food Chemistry, 104(1), 73-80. http://dx.doi.org/10.1016/j.foodchem.2006.10.078.

Pimentel, T. C., Cruz, A. G., \& Prudencio, S. H. (2013). Short communication: Influence of long-chain inulin and Lactobacillus paracasei subspecies paracasei on the sensory profile and acceptance of a traditional yogurt. Journal of Dairy Science, 96(10), 6233-6241. PMid:23932139. http://dx.doi.org/10.3168/jds.2013-6695.

Roberfroid, M. (2005). Inulin: origin, chemistry, biochemistry and technological properties. In M. Roberfroid (Ed.), Inulin-type fructans: functional food ingredients. Boca Raton: CRC Press.

Robinson, R. K. (1995). The potential of inulin as a functional ingredient. British Food Journal, 97(4), 30-32. http://dx.doi. org/10.1108/00070709510085657.
Toneli, J. T. C. L., Mürr, F. E. X., Martinelli, P., Dal Fabbro, I. M., \& Park, K. J. (2007). Optimization of a physical concentration process for inulin. Journal of Food Engineering, 80(3), 832-838. http://dx.doi. org/10.1016/j.jfoodeng.2006.07.012.

Vijn, I., \& Smeekens, S. (1999). Fructan: more than a reserve carbohydrate? Plant Physiology, 120(2), 351-360. PMid:10364386. http://dx.doi. org/10.1104/pp.120.2.351.

XuJie, H., \& Wei, C. (2008). Optimization of extraction process of crude polysaccharides from wild edible BaChu mushroom by response surface methodology. Carbohydrate Polymers, 72(1), 67-74. http:// dx.doi.org/10.1016/j.carbpol.2007.07.034.

Yan, F., Yang, X., Liu, C., Huang, S., Liao, L., \& Fu, C. (2014). Extraction optimization of antioxidant polysaccharides from leaves of Gynura bicolor (Roxb. \& Willd.) DC. Food Science and Technology, 34(2), 402-407. http://dx.doi.org/10.1590/fst.2014.0055.

Yin, G., \& Dang, Y. (2008). Optimization of extraction technology of the Lycium barbarum polysaccharides by Box-Behnken statistical design. Carbohydrate Polymers, 74(3), 603-610. http://dx.doi. org/10.1016/j.carbpol.2008.04.025. 